\title{
CLINICOPATHOLOGICAL CORRELATION OF DIFFERENT SPECTRUM OF HANSEN'S DISEASE
}

\author{
Shahjubin Basir ${ }^{1}$, Bhaskar Gupta², Debajit Das ${ }^{3}$
}

1 Postgraduate Resident, Department of Dermatology, Silchar Medical College, Silchar, Assam, India.

2 Professor and HOD, Department of Dermatology, Silchar Medical College, Silchar, Assam, India.

${ }_{3}^{3}$ Associate Professor and HOD, Department of Dermatology, Silchar Medical College, Silchar, Assam, India.

\section{ABSTRACT}

\section{BACKGROUND}

Hansen's disease contributes to be a significant public health problem. Histopathological evaluation of skin biopsies plays a crucial role in the correct diagnosis of clinically ambiguous cases.

The present study was done to correlate clinically diagnosed new leprosy cases with that of histopathological findings.

\section{MATERIALS AND METHODS}

It was a descriptive study where skin biopsies of 50 newly diagnosed cases were done at our Dermatology Department during the period of one and a half years. The specimen was fixed in 10\% formalin and sent to Pathology Department for routine histopathological examination.

\section{RESULTS}

From this study, it was observed that the commonest age group observed for leprosy was 21 to 30 years. Males are affected twice more commonly than females. The most common clinically diagnosed type was BT Hansen's. It was observed that there was complete agreement between clinical diagnosis and histopathological findings in $68.00 \%$ with maximum concordance in polar lepromatous zone $(84.62 \%)$.

\section{CONCLUSION}

For accurate diagnosis, correlation of clinical and histopathological findings appears to be more useful than any of the parameters alone. In case of any discrepancy, the more advanced finding should be given greater weightage and the case is to be classified and treated accordingly.

\section{KEY WORDS}

Hansen's Disease, 1 and $1 / 2$-Years, Clinical and Histopathological Correlation.

HOW TO CITE THIS ARTICLE: Basir S, Gupta B, Das D. Clinicopathological correlation of different spectrum of Hansen's disease. J. Evolution Med. Dent. Sci. 2018;7(37):4080-4083, DOI: $10.14260 /$ jemds/2018/912

\section{BACKGROUND}

Leprosy is a chronic granulomatous infectious disease that primarily affects the skin and peripheral nerves, even though it can be considered as a systemic disease. The incubation period is from 2.9 years to 5.3 years.[1] The term leprosy is a tribute to Norwegian physician Gerhard Armauer Hansen who identified the bacillus Mycobacterium Leprae as the course of the disease in 1873.[2] Ridley-Jopling classified leprosy according to clinical, bacteriological, immunological and histological criteria into TT (Tuberculoid Tuberculoid), BT (Borderline Tuberculoid), BB (Borderline Borderline), BL (Borderline Lepromatous) and LL (Lepromatous Lepromatous).[3] Exact typing of Leprosy clinically sometimes can be very difficult, for which histopathological examination should be done in all cases. No multibacillary cases should be treated as paucibacillary.

\section{MATERIALS AND METHODS}

It was a descriptive study, where 50 skin biopsies were obtained from patients clinically diagnosed as leprosy during

'Financial or Other Competing Interest': None.

Submission 24-07-2018, Peer Review 25-08-2018,

Acceptance 31-08-2018, Published 10-09-2018.

Corresponding Author:

Dr. Shahjubin Basir,

Postgraduate Resident,

Department of Dermatology,

Silchar Medical College, Silchar-788014, Assam, India.

E-mail: dr.shahjubinbasir@gmail.com

DOI: $10.14260 /$ jemds $/ 2018 / 912$

\section{(c) $(1) \odot$}

the period of one and a half years in the Dermatology Department in Silchar Medical College and Hospital and sent to Department of Pathology and follow-up was done. A comparative study was done in this case.

\section{Data was analysed by-}

1. Comparing the clinical diagnosis with histopathological diagnosis.

2. Evaluating the concordance of histopathological and clinical diagnosis in each of the cases.

Concordance in case of indeterminate and histoid leprosy were also included.

\section{RESULTS}

Out of 50 clinically and histopathologically diagnosed cases, it was seen in age group starting from $1^{\text {st }}$ decade to 7 th decade. Most common cases occurred in the age group of 21 to 30 years. $28 \%$ ( 14 cases) and least common cases occurred in 10 to 20 years of age $6 \%$ ( 3 cases).

\begin{tabular}{|c|c|c|}
\hline Age & Number of Cases & Percentage \\
\hline $10-20$ & 3 & 6 \\
\hline $21-30$ & 14 & 28 \\
\hline $31-40$ & 4 & 8 \\
\hline $41-50$ & 9 & 18 \\
\hline $51-60$ & 12 & 24 \\
\hline $61-70$ & 8 & 16 \\
\hline \multicolumn{2}{|c|}{ Table 1. Age distribution of Cases } \\
\hline
\end{tabular}




\section{Sex-Wise Distribution}

Out of 50 clinically detected cases, $64 \%$ cases (32 cases) were males and $36 \%$ cases (18 cases) were females.

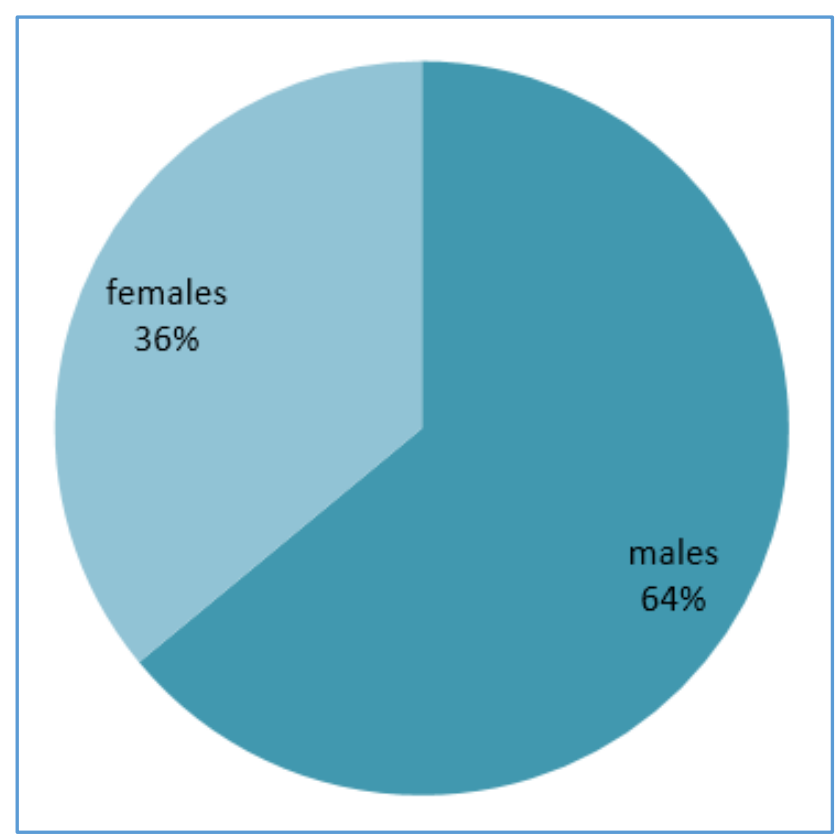

Table 2. Sex distribution of Cases

Out of 50 clinically diagnosed cases, $14 \%$ cases ( 7 cases) were diagnosed as TT. $32 \%$ cases (16 cases) were diagnosed as BT. $6 \%$ cases ( 3 cases) were diagnosed as BB. $10 \%$ cases ( 5 cases) were diagnosed as BL. $26 \%$ cases (13 cases) were diagnosed as LL. 8\% cases (4 cases) were diagnosed as $\mathrm{HH}$. $4 \%$ cases ( 2 case) were diagnosed as IL.

\begin{tabular}{|c|c|c|}
\hline Type & No. of Cases & Percentage \\
\hline TT & 7 & $14 \%$ \\
\hline BT & 16 & $32 \%$ \\
\hline BB & 3 & $6 \%$ \\
\hline BL & 5 & $10 \%$ \\
\hline LL & 13 & $26 \%$ \\
\hline HH & 4 & $8 \%$ \\
\hline IL & 2 & $4 \%$ \\
\hline \multicolumn{2}{|c|}{ Table 3. Showing Clinically Diagnosed Cases } \\
\hline
\end{tabular}

\section{Modified Ziehl-Neelsen Staining}

All cases of BLHD, LLHD and histoid Hansen's showed 100\% positivity. 2 cases (75\%) of BBHD showed positivity, whereas all cases of TTHD, BTHD and IL did not show any positivity to modified Ziehl-Neelsen stain.

\begin{tabular}{|c|c|c|}
\hline HPE Diagnosis & No. of Positive Cases & Percentage \\
\hline TT $(\mathrm{N}=8)$ & 0 & $0 \%$ \\
\hline $\mathrm{BT}(\mathrm{N}=16)$ & 0 & $0 \%$ \\
\hline $\mathrm{BB}(\mathrm{N}=3)$ & 2 & $75 \%$ \\
\hline $\mathrm{BL}(\mathrm{N}=6)$ & 6 & $100 \%$ \\
\hline LL $(\mathrm{N}=13)$ & 13 & $100 \%$ \\
\hline $\begin{array}{c}\text { Histoid Hansen's } \\
(\mathrm{N}=3)\end{array}$ & 3 & $100 \%$ \\
\hline IL $(\mathrm{N}=1)$ & 0 & $0 \%$ \\
\hline \multicolumn{3}{|c|}{ Table 3. Modified Ziehl-Neelsen Positivity } \\
\hline
\end{tabular}

\section{Concordance with Clinical Diagnosis}

Maximum clinicohistopathological concordance was seen with LLHD (84.62\%) followed by Histoid Hansen's (75\%), BB (66.67\%), BTHD (62.50\%), BL (60.00\%), TTHD (57.15\%) and IL $(50.00 \%)$. Overall concordance of diagnosis of spectrum of Hansen's disease was seen in $68 \%$ of cases (34 cases). Disagreement was seen in $32 \%$ cases (16 cases).

\begin{tabular}{|c|c|c|c|c|c|c|c|c|c|}
\hline \multicolumn{2}{|c|}{ 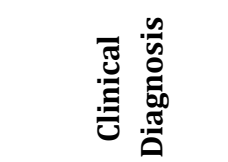 } & \multicolumn{8}{|c|}{ Histopathological Diagnosis } \\
\hline & & TT & BT & BB & BL & $\mathbf{L L}$ & IL & HL & \multirow{2}{*}{ 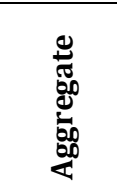 } \\
\hline$\sum_{i}^{\infty}$ & है & & & & & & & & \\
\hline TT & 7 & $\begin{array}{c}4 \\
(57.15 \%)\end{array}$ & $3(42.85 \%)$ & & & & & & $57.15 \%$ \\
\hline BT & 16 & $\begin{array}{c}4 \\
(25.00 \%)\end{array}$ & $10(62.50 \%)$ & $1(6.25 \%)$ & $1(6.25 \%)$ & & & & $62.50 \%$ \\
\hline BB & 3 & & $1(33.33 \%)$ & $\begin{array}{c}2 \\
(66.67 \%)\end{array}$ & & & & & $66.67 \%$ \\
\hline $\mathrm{BL}$ & 5 & & $1(20.00 \%)$ & & $3(60.00 \%)$ & $1(20.00 \%)$ & & & $60.00 \%$ \\
\hline LL & 13 & & & & $2(15.38 \%)$ & $\begin{array}{c}11 \\
(84.62 \%)\end{array}$ & & & $84.62 \%$ \\
\hline IL & 2 & & $\begin{array}{c}1 \\
(50.00)\end{array}$ & & & & $1(50.00 \%)$ & & $50.00 \%$ \\
\hline HL & 4 & & & & & $1(25.00 \%)$ & & $3(75.00 \%)$ & $75.00 \%$ \\
\hline Total & 50 & 8 & 16 & 3 & 6 & 13 & 1 & 3 & \\
\hline \multicolumn{10}{|c|}{ Table 4. Showing Clinicohistopathological Correlation } \\
\hline
\end{tabular}




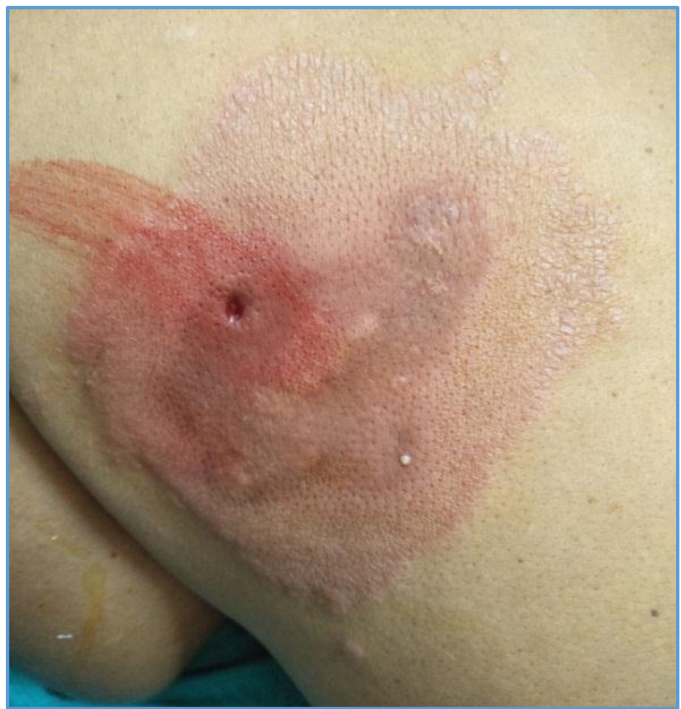

BT Hansen (Punch Biopsy Done)

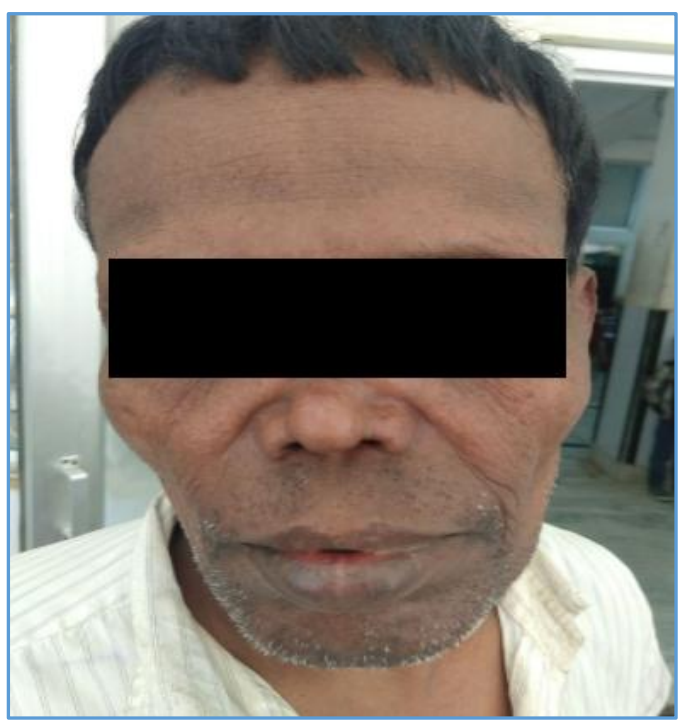

HD LL Facies

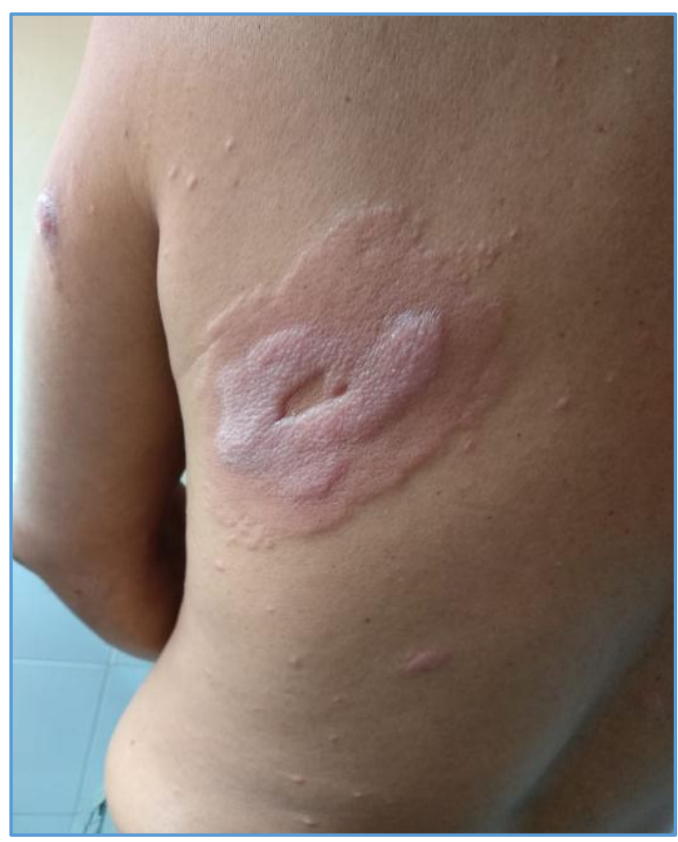

BB Hansen

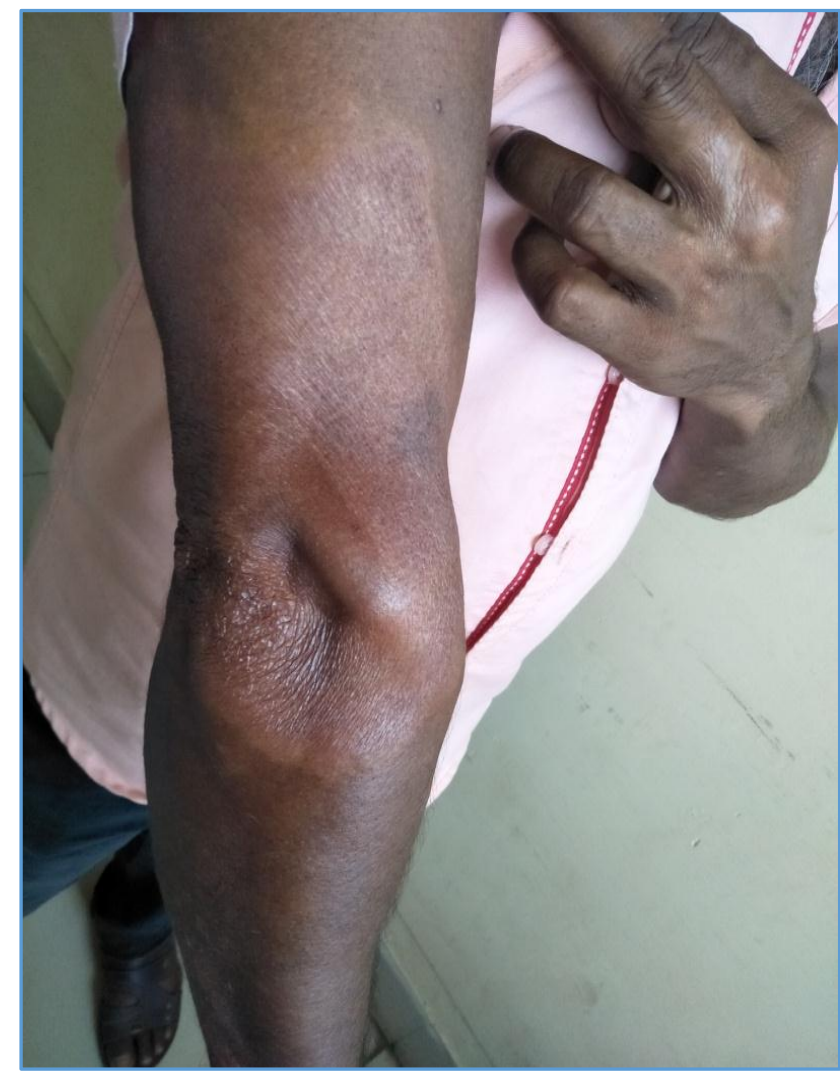

BT Hansen

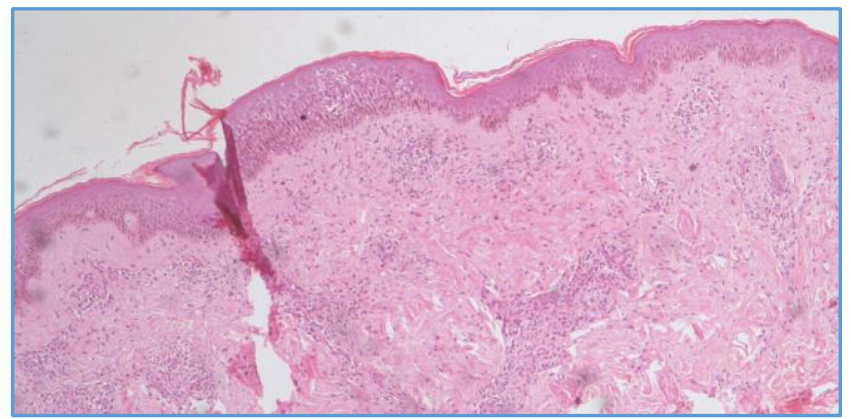

Histopath of LL HD

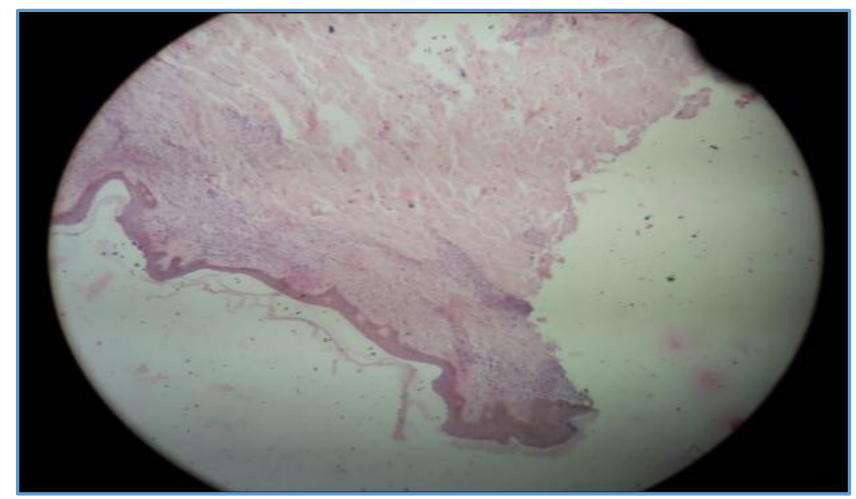

Histopath of BL HD

\section{DISCUSSION}

In our present study, maximum incidence was seen in age group 21 - 30 years (28\%) and the lowest incidence was seen in age group 10 - 20 years (6\%). 64\% were males and $36 \%$ were females with a ratio of 1.7: 1. Similar findings were found with Suri SK et al,4 Sehgal et al, ${ }^{5}$ Nadkarni et $\mathrm{al}^{6}$ and 
Bijjaragi et al. ${ }^{7}$ With modified Ziehl-Neelsen stain for acid fast bacilli $100 \%$ positivity was noted in LLHD, BLHD and Histoid Hansen's. The finding in LLHD and BLHD are comparable with the study of Aryon de Almeda et al, which shows 100\% for BLHD and LLHD. 8 In the present study, complete concordance of clinical and histopathological diagnosis was seen in $68 \%$ of cases with maximum concordance in the diagnosis of LLHD (84.62). This finding is comparable with the study of Niranjana Moorthy et al, where overall concordance was seen in $62.63 \%$ of cases with maximum concordance in the diagnosis of polar lepromatous Hansen's disease $(80 \%){ }^{9}$

\section{CONCLUSION}

Classification of early types of leprosy clinically accurately may be difficult sometimes. So pathological examination should be done in all cases and clinical and histopathological correlation is important. However, certain degree of overlap is seen both clinically and histologically. So clinicohistopathological correlation along with bacterial index appears to be more useful for accurate typing of leprosy.

\section{REFERENCES}

[1] LockWood DN, Sarno E, Smith WC. Classifying leprosy patients - searching for the perfect solution? Lepr Rev 2007;78(4):317-20.

[2] Eidt LM. Breve historia da hanseniase: sua expansao do mundo para as Americas, o Brasil e o Rio Grande do Sul e sua trajetoria na saude publica brazileira. Saude Soc 2004;13(2):76-88.
[3] Ridley DS, Jopling WH. Classification of leprosy according to immunity. A five group system. Int J Lepr Other Mycobact Dis 1966;34(3):255-73.

[4] Suri SK, Iyer RR, Patel DU, et al. Histopathology and clinic-pathological correlation in Hansen's disease. J Res Med Den Sci 2014;2(1):37-44.

[5] Sehgal VN, Ghorpade A, Saha K. Urban leprosy an appraisal from Northern India. Lepr Rev 1984;55(2):159-66.

[6] Nadkarni NS, Rege VL. Significance of histopathological classification in leprosy. Indians J Lepr 1999;71(3):325-32.

[7] Bijjaragi S, Kulkarni V, Suresh KK, et al. Correlation of clinical and histopathological classification of leprosy in post elimination era. Indian J Lepr 2012;84(4):2715.

[8] De Almeida BJA, Jambeiro J, Cirqueira JSO, et al. Retrospective histopathological classification of 1, 108 skin biopsies from patients clinically suspected of having leprosy from Bahia, Northeast Brazil. Revista da sociedade Brazileria de medicina Tropical 1998;31(6):533.

[9] Moorthy BN, Kumar P, Chatura KR, et al. Histopathological correlation of skin biopsies in leprosy. Ind J Dermatol Venereol and Leprol 2001;67(6):299-301. 